\title{
An investigation of the characteristics, causes, and consequences of June 13, 2017, landslides in Rangamati District Bangladesh
}

\author{
Joynal Abedin ${ }^{1}$, Yasin Wahid Rabby ${ }^{2^{*}}$ D, Ikramul Hasan ${ }^{1}$ and Humaira Akter ${ }^{1}$
}

\begin{abstract}
The primary purpose of this study is to find out and discuss the characteristics, causes, and consequences of the landslides of June 13, 2017, in the Rangamati district Bangladesh. Since rainfall triggered the landslides, debris flow accounts for $40.45 \%$ of the landslides. Most of the landslides are small (mean 274. $2 \mathrm{~m}^{2}$ with a standard deviation of $546.1 \mathrm{~m}^{2}$ ). Size of $62.30 \%$ of the landslides was $<100 \mathrm{~m}^{2}$. The probability density of $50-100 \mathrm{~m}^{2}$ landslides is the highest and with the increase of the size of landslides, probability density decreases. It indicates the chance of large landslides $\left(>1000 \mathrm{~m}^{2}\right)$ is low. Frequency ratio, logistic regression, and Spearman's rank correlation were used to find out the relationship between 15 landslide causal factors including elevation, slope, rainfall, aspect, land use/land cover, land use/land cover change and distance to the road network with the occurrences and size of landslides. Among the land use/land cover types built-up areas [frequency ratio $(F R)=5.67$ ], among land-use land-cover change types: vegetation to built-up $(F R=5.31)$ are the most prone areas to landslides. Logistic regression models found six causal factors were statistically significant, including slope (Coefficient, $\beta=1.05$ ), and distance to the road network ( $B=0.44)$. The size of the landslides had a significant relationship with five causal factors, including annual rainfall $(\rho=0.52)$, and elevation $(\rho=0.24)$. Paired sample t-test on pre-event and post-event monthly incomes revealed that landslides had a significant impact on different occupations of the local people. People involved in primary economic activities like the slash and burn agriculture (locally known as jhum cultivation) and fishing are the worst sufferers of landslides as they experienced a significant fall of income after the landslides. The findings of the study would help the policymakers to mitigate landslide hazards in the Rangamati district.
\end{abstract}

Keywords: Landslides, Rangamati, Probability density, Frequency ratio, Logistic regression

\section{Introduction}

Landslides are the third most crucial natural disasters in the world, which cause damage to infrastructure and loss of lives (Zillman 1999; Yilmaz 2009; Su et al. 2010; Chen et al. 2017). Factors that are behind the landslides can be divided into causative factors and triggering factors (Guzzetti et al. 2012). Causative factors create a suitable

\footnotetext{
* Correspondence: yrabby@vols.utk.edu

${ }^{2}$ Department of Geography, University of Tennessee, Knoxville, Burchfiel Geography Building, Knoxville, TN 37996-0925, USA

Full list of author information is available at the end of the article
}

condition for landslides, which include slope, geology, aspect, and land-use land-cover. Triggering factors initiate the landslides, which include prolonged rainfall and earthquake (Chen et al. 2017). Moreover, human activities, including building and road construction and intense plantation agriculture on slopes, can accelerate it (Islam et al. 2017a, 2017b). Due to the population growth and increased interest in tourism in some parts of the world, the rate of development in the hilly areas has increased. These developments have increased the economic loss caused by 
landslides (Petley et al. 2005; Guha-sapir et al. 2011; Guzzetti et al. 2012).

In recent days, the number of deaths and damages to infrastructures caused by landslides has increased in Chittagong Hilly Areas (CHA) of Bangladesh. In the last 30 years, landslides have caused the death of more than 350 people (Islam et al. 2017a, 2017b). A series of landslides occurred during June 2017 due to incessant rainfall in 145 places of CHA, which caused 168 deaths, damaged 40 thousand houses. Rangamati, an indigenous hilly district, suffered the highest negative consequences (WHO 2017) in its history. These landslides in the Rangamati district claimed lives of 126 in total and severely damaged 6000 dwelling, roads, telecommunication systems. The total economic loss was about USD 223 million (UNRC 2017; Ferdous et al. 2017; Haque et al. 2018).

As landslides have become an increasingly important issue in the CHA, various works have been carried out mostly on the landslide susceptibility mapping using different qualitative and quantitative techniques (Ahmed 2015a, 2015b; Ahmed and Dewan 2017; Rahman et al. 2017). These studies covered the Chittagong Metropolitan Area (CMA) and Cox's Bazar municipality, which are the two largest cities of CHA (Ahmed 2015a, 2015b). Sifa et al. (2019) produced event-based landslide susceptibility maps of the four Upazilas (Third-Order Administrative Boundary of Bangladesh) of the Rangamati district (Second-Order Administrative District). They used a remote sensing technique to prepare the landslide inventory of June 13, 2017, landslides. Until now, no study has developed a field investigation-based landslide inventory and discussed the characteristics of June 13, 2017, landslides in the Rangamati district. Although landslides pose a severe threat to human lives and cause damage to the socio-economy of an area, very few studies have attempted to quantify the impact of landslides on socio-economic systems (Mertens et al. 2017). In this study, detailed research was carried out on the features and implications of the June 2017 landslides in the three most affected Upazilas (the third-order administrative boundary of Bangladesh) (Rangamati Sadar, Kawkhali and Kaptai) of Rangamati district. Our research has three objectives: 1 . Discussing the distribution and characteristics of June 2017 landslides; 2. Finding the relationship of these landslides with different landslide causative factors and 3. Discussing the consequences of these landslides on socio-economy of the local people.

To show and discuss the distribution of the June 13, 2017, landslides frequency and probability densities were used. Frequency ratio (FR) and logistic regression (LR) were used to find out the relationship of landslides with the 15 causal factors: elevation, slope, plan curvature and profile curvature, rainfall, aspect, topographic wetness index (TWI), stream power index (SPI), land use/ land cover, land use/land cover change (1998-2018), distance to road network, distance to drainage network, distance to fault lines, geology, and normalized difference vegetation index (NDVI). To reveal the impact of landslides on the socio-economy, we assess the effects of June 13, 2017, landslides on the monthly income of the local people.

\section{Study area}

Rangamati lies between $22^{\circ} 27^{\prime}$ and $23^{\circ} 44^{\prime}$ north latitudes and $91^{\circ} 56^{\prime}$ and $92^{\circ} 33^{\prime}$ east longitudes (Fig. 1). It is circumscribed on the north and east by India, on the south by Bandarban district, and the west by Khagrachari and Chittagong districts. Rangamati district encompasses $6116.19 \mathrm{~km}^{2}$ (Rangamati Hill District Council 2011) and is the largest district in the country in terms of area. Rangamati has ten Upazilas, and for this study, three of them were selected: Rangamati Sadar, Kawkhali, and Kaptai Upazila. These three were the most affected Upazilas by landslides in the Rangamati district (Sifa et al. 2019). The study area covers an area of $1145 \mathrm{~km}^{2}$ (Rangamati Sadar, Kawkhali, and Kaptai encompass 547, 339, and $259 \mathrm{~km}^{2}$ respectively), of which $218 \mathrm{~km}^{2}$ is riverine, $497 \mathrm{~km}^{2}$ is under forest vegetation (BBS 2011).

\section{Geology and climate}

The study area is underlain by tertiary and quaternary sediments that have been folded, faulted, and uplifted and then profoundly dissected by rivers and streams. Dhihing, Dupi tila, Girujan clay, Bhuban, Bokabil, and Tipam sandstone formation are present throughout the study area. The highest susceptibility of landslides is in Bhuban and Bokabil formation because there is an alteration of sandstone and shale in their geology (Haque et al. 2018). The bedrock and soil structure of these hills are not stable, and that is why the areas are highly prone to landslides (Islam et al. 2017a, 2017b).

Climatically, Bangladesh is in the tropical monsoon region, and its climate is characterized by high temperatures, heavy rainfall, often excessive humidity, and fairly marked seasonal variations (Banglapedia 2014). Rangamati experiences tropical monsoon climate, and annual average temperature varies from a maximum of $36.5^{\circ} \mathrm{C}$ to a minimum of $12.5^{\circ} \mathrm{C}$, and annual rainfall is $2673 \mathrm{~mm}$ with humidity level 71.6\% (BBS 2011).

\section{Socio-economic background}

The population of the study area is around 243,999 (52\% tribal and $48 \%$ Bengali). The population density is about 97 per $\mathrm{km}^{2}$ and with a 1.1:1 male to female ratio. The overall literacy rate of the study area is $56 \%$ (Rangamati Sadar 64.5\%, Kawkhali 44.2\%, and Kaptai 60\%) (BBS 2011). Most of the people in this area are involved in agricultural activities, and large portions of tribal people 


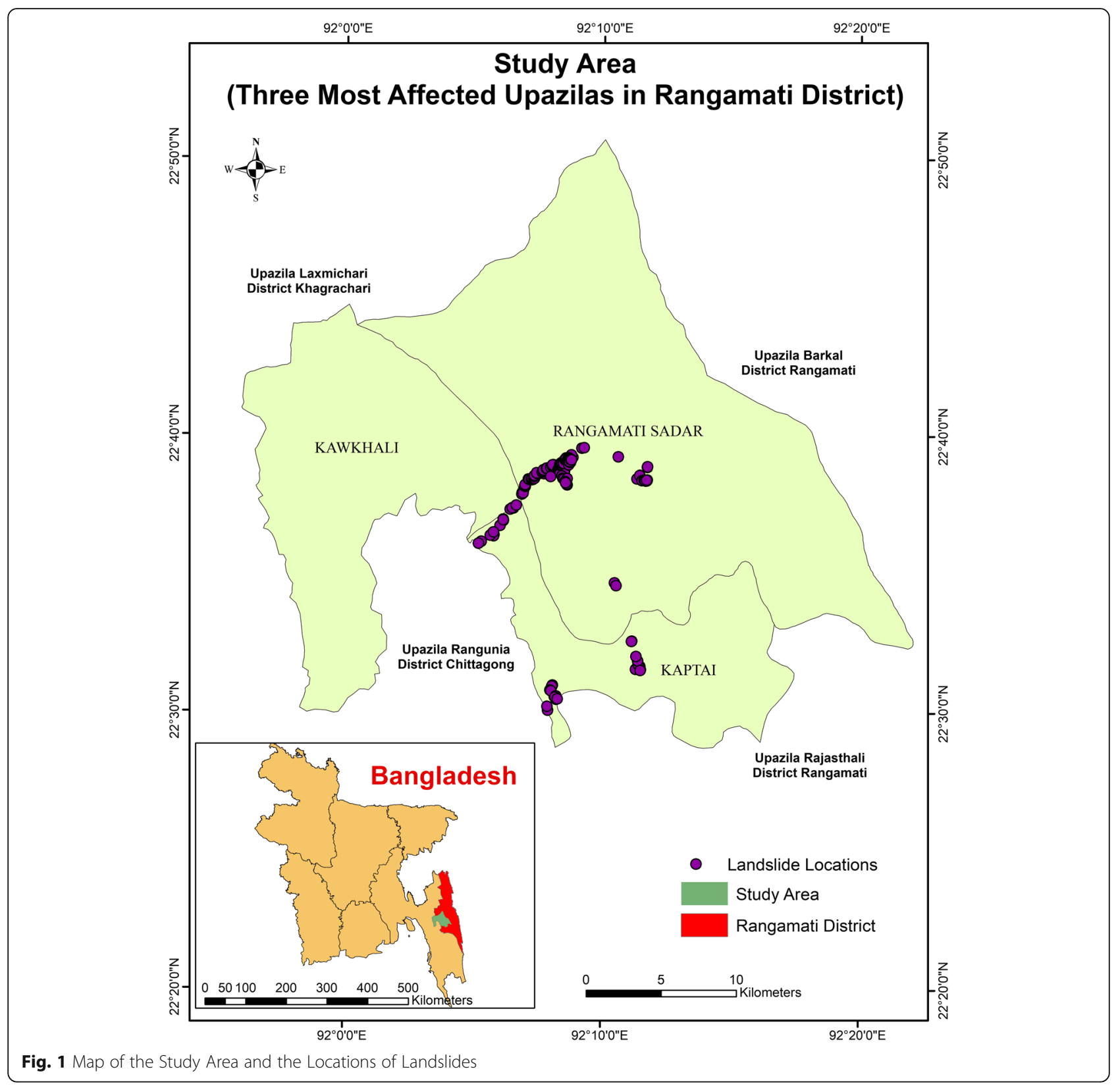

practice slash and burn agriculture (locally known as jhum cultivation) (Banglapedia 2015).

\section{General description of the landslide}

Landslides killed at least 152 people in CHA between 12 and 13 June 2017 (Prothom Alo 2017). These landslides were triggered by excessive rainfall $(510 \mathrm{~mm}$ rainfall between 12 to June 14, 2017 ( $48 \mathrm{~h})$ ). The landslide events affected 79,234 persons. Among these people, 34,000 were severely impacted as they lost their houses. In Rangamati Hill district 118 (including two missing persons), people have died as of June 21 while leaving 227 injured (Prothom Alo 2017). As per the data of the Rangamati district administration, about 12,450 families have suffered losses (UNPO 2017), 1500 houses were destroyed, and 2000 homes were partially damaged due to landslides (UNDP 2017).

\section{Methodology}

The study was divided into three parts: 1 . Field Investigation to record the landslides occurred on June 13, 2017. 2. Field Investigation to know the impact of landslides on the socio-economy of the study area. 3 . To find out the relationship of different causal factors with the landslides occurred in the study area. 


\section{Landslide inventory mapping}

Landslide inventory includes detailed information about the landslides, including the location, size, and type of landslides. It can be historical, which included landslides that occurred at different times in an area and eventbased, which contains the landslides triggered by a single event. (Guzzetti et al. 2012).

Participatory field mapping was used to prepare an event-based (June 13, 2017) landslide inventory (Samodra et al. 2015; Rabby and Li 2019; Rabby and Li 2020). We went through the newspaper articles and talked to the officials of the Disaster Management Department of the People's Republic of Bangladesh during July 2017 to select the locations where field mapping would be carried out. Detail procedure of the field mapping is given in Rabby and $\mathrm{Li}$ 2019. This research mapped 131 landslides in the study area (Fig. 1) and (Fig. 2) shows the images of some of the landslides that caused casualties in the study area. We recorded the location, size, and types of landslides.

\section{Socio-economic survey}

A detailed exploratory field investigation was conducted in December 2018 to know the impact of landslides on socio-economy. Field data were collected through semistructured questionnaires from the directly affected area of ten unions under three Upazilas. A pilot survey was conducted, and the questionnaire was modified according to the responses. A purposive random sampling method was conducted throughout the study area. A total of 120 samples were collected and based on fatality 70 samples from Rangamati Sadar, 30 from Kawkhali, and 20 from Kaptai according to (Eq. 1) under a $90 \%$ confidence level. Z

$$
n=\left(Z_{\alpha / 2} \times \frac{\sigma}{E}\right)^{2}
$$

Where $\mathrm{n}=$ sample size, $\mathrm{Z}_{\alpha / 2}=$ confidence level, $\sigma=$ standard deviation, and $\mathrm{E}=$ error.

Different socio-economic data were collected from the survey, which includes monthly and source of incomes of the respondents. These data were divided into three times: before (during May), during (during June) and after (during July) the landslides. Paired sample t-tests were applied to find out whether the monthly income before, during, and after the landslides were significantly different. Statistical Package for the Social Science (SPSS-20) software was used for this purpose.

\section{Analysis of the characteristics and causes of landslides}

Frequency density and probability density of landslides were used to describe the characteristics of landslides. These two densities show the density of landslides in an area range. Frequency density is the ratio of the number of landslides in a specific area range and the interval of that area range. The probability density is calculated by dividing frequency density with the total number of landslides in the study area (Zhang and Huang 2018; Zhang et al. 2019). As mentioned before in this study, 15 landslide causal factors were used, and they were grouped into geological factors, topographical factors, and environmental and anthropogenic factors.

\section{Geological factors}

In this study, the geology and distance to fault lines (Fig. 3a and b) of the study area were used, provided by the Geological Survey of Bangladesh (GSB) as the geological factor. Geology is related to the permeability and strength of rocks and soil of an area and, thus, the landslides (Ayalew and Yamagishi 2005). In the study area, there are eight geological formations. From which ava: Valley Alluvium and Colluvium and lake are free of landslides as they are either flatlands or waterbodies. Landslides occur in six other structures. From which, QTdd: Dihing and Dupi Tila Formation Undivided, QTdt: Dupi Tila Formation and QTg: Girijuan Clay are bedrocks. On the other hand, Tbb: Boka Bil Formation, Tb: Bhuban Formation and Tt: Tipam Sandstone have an alteration of sandstone and shale (Haque et al. 2018).

Fault lines indicate tectonic breaks, and it decreases the strength of the rock. Generally, an area closer to the Faultline is more prone to landslide than the area further away (Netra et al. 2014). This study used the Euclidean Distance tool in ArcGIS 10.7 to measure the distance to the fault lines and divided it into five classes (Fig. 3b) using the Jenks natural break method.

\section{Topological factors}

This study used elevation, slope, plan curvature and profile curvature, aspect, distance to drainage network, Topographic Wetness Index (TWI), and Stream Power Index (SPI) as topological factors.

Elevation does not have a direct connection with landslides but can be a proxy factor (Wang and Li 2017). It shows the local relief, and in higher elevation, anthropogenic activities like road density decrease (Ayalew and Yamagishi 2005). Advanced Spaceborne Thermal Emission and Reflection Radiometer (ASTER) Global Digital Elevation Map (GDEM) (30 m resolution) was used for the elevation map of the study area (Fig. 3c). Like the distance to the fault lines, the elevation was divided into five classes (Fig. 3c). Later for all the continuous factors (other than land use/land cover, land use/land cover change, geology), Jenks's natural break method in ArcGIS 10.7 was used to divide them into five classes.

Traditionally, the slope is the most crucial factor of landslides. Generally, in lower slopes, landslides are rare. With the increase of slope up to a certain extent, landslides increase (Chen et al. 2017). The study used the 

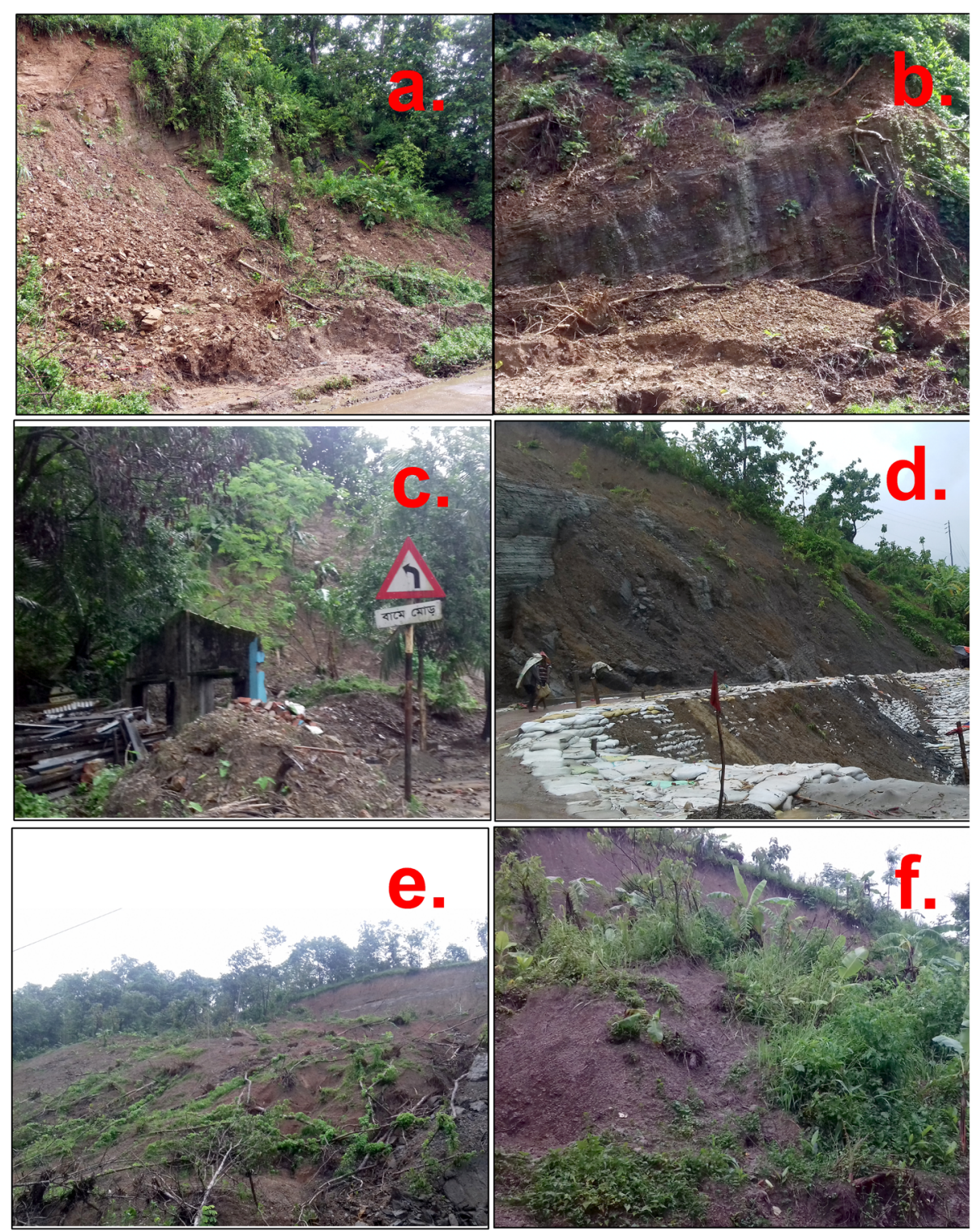

Fig. 2 Images of Some of the Landslides and Associated Damages Occurred on the June 13, 2017: a. and b. Landslides in the ChittagongRangamati Highway; c. A Collapsed School Building in Rangamati Sadar; d. Damaged Road and Nearby Bridge; e. and f. Damaged Plantation Agriculture Fields

Slope tool of ArcGIS 10.7 to calculate the slope from ASTER GDEM (Fig. 3d).

The concave and convex nature of the slope is shown by the plan curvature, and profile curvature. The tensile force along the slope increases with the increase of curvature. Therefore, plan curvature, and profile curvature are associated with slope instability (Wang and Li 2017). ArcGIS 10.7 was used to produce the plan curvature, and profile curvature (Fig. 3e and f) maps and divided it into three classes: concave, convex, and flat.

Aspect is the compass direction that a slope face. It is measured in degrees from the north in a clockwise direction and ranging from $0^{\circ}-360^{\circ}$ (Bui et al. 2011). The duration of sunlight, evapotranspiration, moisture retention, vegetation cover, and distribution depend on the aspect of an area. These things have indirect effects on landslides, and thus aspect indirectly controls the occurrence of landslides (Chen et al. 2017). This study used the Aspect tool in ArcGIS to produce the aspect map (Fig. 4a) of the study area.

River and streams play an essential role in the erosion of nearby slopes of the water bodies and can indirectly influence the landslides (Rahman et al. 2017). Here, the Euclidean Distance tool of ArcGIS 10.7 was used. It measures the distance of each raster cell from the river or drainage network (ESRI 2017). Distance to the drainage network was divided into five classes (Fig. 4b). 

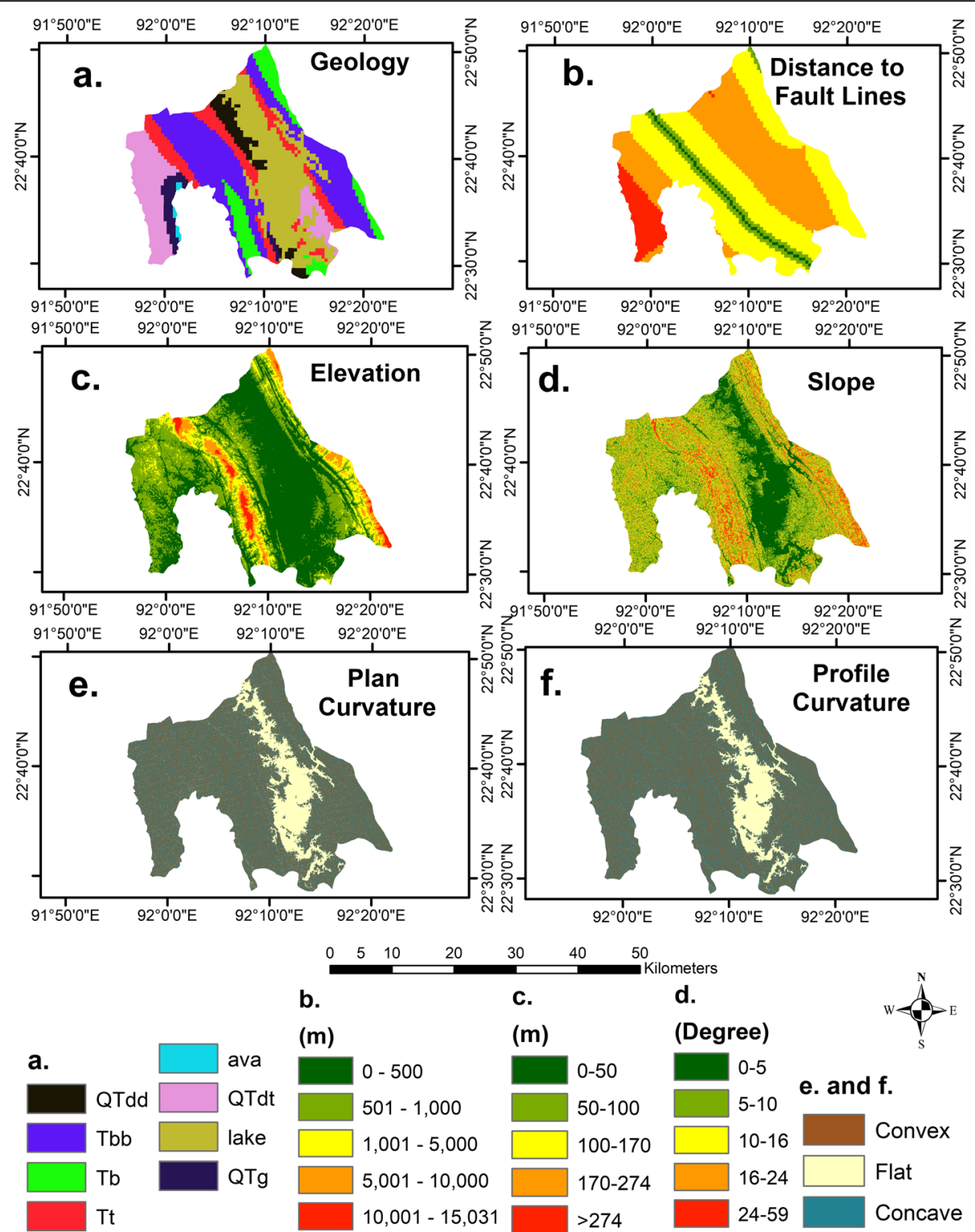

b.

(m)

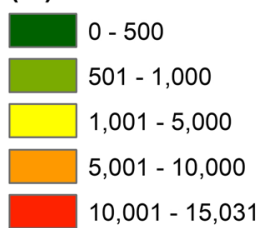

c.

(m)

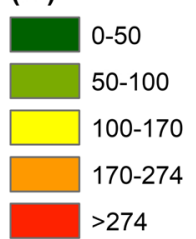

d.

(Degree)

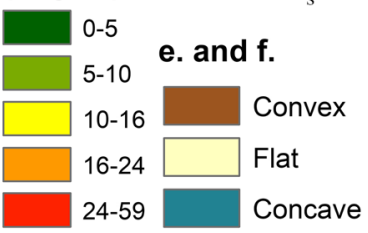

Fig. 3 Landslide Causative Factors: a. Geology; b. Distance to Fault Lines; c. Elevation; d. Slope; e. Plan Curvature; f. Profile Curvature. Qtdd= Dihing and Dupi Tila Formation; Tbb = Boka Bil Formation; Tb = Bhuban Formation; Tt = Tipam Sandstone; ava = Valley Alluvium and Colluvium; QTdt = Dupi Tila Formation; QTg = Girujan Clay

Flow direction, flow accumulation, and soil moisture concentration limit the distribution of landslides (Ayalew and Yamagishi 2005). Two proxy factors called TWI and SPI were used in this study. TWI has a relationship with groundwater conditions and soil moisture (Chen et al. 2017). It is the function of the upstream contributing area per unit, and the slope of the area (Eq. 2). TWI (Fig. 4c) is calculated from ASTER GDEM.

$$
T W I=\ln \left(\frac{A}{b \tan \beta}\right)
$$

Where, $\mathrm{A}=$ Flow accumulation in square meters; $\mathrm{b}=$ Pixel width over which water flows; $\beta=$ Slope in Degree.

SPI measures the erosive power of stream or water flow. Higher the SPI value of an area, the more the chance of landslides as it is related to steeper slope at the foothill (Chen et al. 2017). SPI (Fig. 4d) is calculated (Eq. 3) using ASTER GDEM.

$$
S P I=\frac{A \tan \beta}{b}
$$




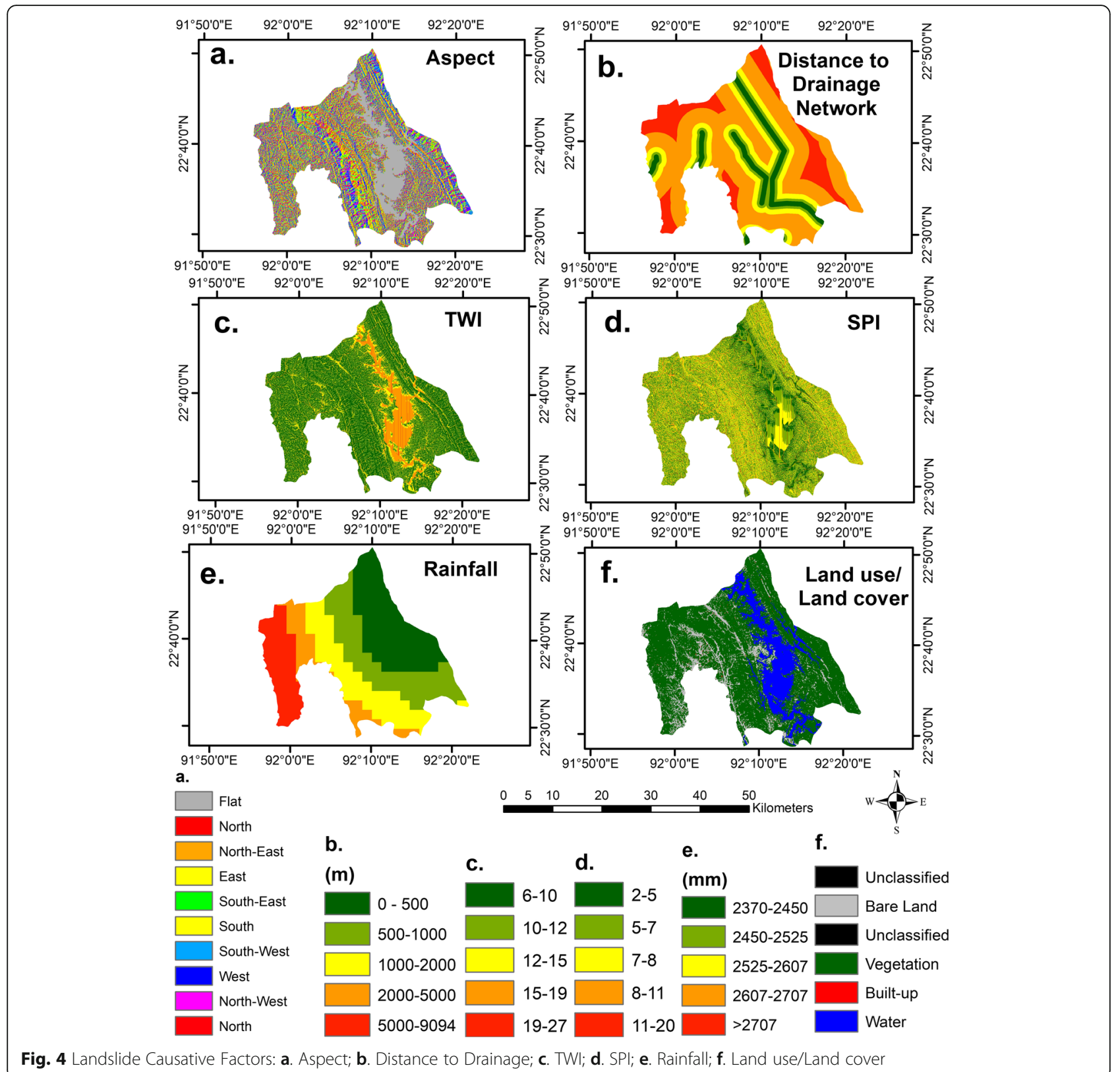

Where, $\mathrm{A}=$ Flow accumulation in square meters; $\mathrm{b}=$ Pixel width over which water flows; $\beta=$ Slope in Degree.

\section{Environmental and anthropogenic factors}

Rainfall, land use/land-cover (2018), land use/land cover change (1998-2018), distance to road network, and Normalized Difference Vegetation Index (NDVI) were used as environmental and anthropogenic factors.

Data of 5 weather stations of Bangladesh Meteorological Department (BMD) had been used to produce an annual rainfall map of the study area. Kriging interpolation method was used to produce a spatial map of the annual rainfall (Fig. 4e).
This Study used two Landsat images (Landsat5- Date of Acquisition: 24/12/1998; Landsat8- Date of Acquisition: 29/11/2018) to assess the spatial and temporal land use/land cover change of the study area. All the images were cloud-free, and necessary geometric and radiometric corrections were performed. A modification of the Anderson scheme Level-I method was used (Anderson 1976). The image classification was conducted using a supervised maximum likelihood classification (MLC) algorithm ( Li et al. 2014; Traore et al. 2018). For each category, 60 polygons were digitized based on the visual interpretation of the locations on Google Earth and the image itself. The land cover maps were validated using 
Rangamati district guide maps and Google Earth images. Based on the knowledge obtained from the study area and the spectral characteristics of the satellite images, four land-cover categories, namely built-up, water bodies, vegetation, and bare land, were classified. However, in the classified types obtained from the MLC algorithm, misclassification was observed. A post-classification refinement to improve the accuracy of the classification was applied (Dewan and Yamaguchi 2008). Ground truth information was also useful for refining the process. Finally, to remove the salt-and-pepper effect, a $3 * 3$ majority filter was applied to the classified land covers (Fig. 4f) (Harris and Ventura 1995; Lillesand and Kiefer 1999).

A post comparison of change was used to determine the land/use land/cover changes. It is the most common approach to compare data from different years (Yuan et al. 2005. The change detection matrix for the period was produced using pixel by pixel method (Jensen and Ramsey 1987). Finally, it was presented as a land/use land/cover change (1998-2018) map (Fig. 5a).

In this study, to show the impacts of vegetation on landslides, the normalized vegetation index (NDVI) was mapped (Fig. 4b) from LandSat 8 level 2 imagery of 11/ 10/2017. The equation for NDVI is given below (Eq. 4)

$$
N D V I=\frac{I R-R}{I R+R}
$$

Where IR is infrared value, and $\mathrm{R}$ is the red portion of the electromagnetic spectrum. NDVI value ranges from -1 to 1 . Higher the value, the higher is the vegetation. A negative value indicates water bodies. A lower positive value indicates bare land and urban areas.

Roads help in runoff concentration, and road cuts damage the slope structure. If the necessary precautionary measures are not taken, landslides can occur near the roads (Chen et al. 2017). The study used the Euclidean distance tool of ArcGIS 10.7 to measure the distance to the road network (Fig. 5c).

\section{Percentages of landslides and frequency ratio}

In this study, we used frequency ration (FR) and logistic regression (LR) models. These two models will not directly imply the causes of landslides in the study. It is because the mechanisms of landslides are very complicated (Rahman et al. 2017). Nevertheless, these two models will give an idea of which factors are contributing to landslides. FR is a bivariate statistical model, whereas LR is a multivariate model (Althuwaynee et al. 2014). The FR model assesses the relationship between landslide occurrence and one causal factor at a time (Chen et al. 2017). LR determines the relationship of landslide occurrence and multiple causal factors (Ayalew and Yamagishi 2005).
The frequency ratio (Eq. 5) shows the relationship between landslide inventory (landslide locations) and landslide causal factors. It is the ratio of the area where landslides occurred to the total area (Vakhshoori and Zare 2016). FR $>1$ for a class of the factors indicates an association with landslides, while $\mathrm{FR}<1$ means no association. Higher the FR value, the greater is the contribution of that factor to landslides. In the FR model, we must divide each of the causal factors into user-defined classes (Vakhshoori and Zare 2016). For example, we can split a factor $i$ into $j$ number of sub-classes. The FR model gives FR values for each of the sub-class. It helps to understand which sub-class of the factor has more association with landslides than the other sub-classes. It cannot give the overall association of a factor with the landslides (Chen et al. 2017).

$$
F R=\frac{\left(\frac{N_{i j}}{N_{\text {total }}}\right)}{\left(\frac{A_{i j}}{A_{\text {total }}}\right)}
$$

Where, $\mathrm{N}_{\mathrm{ij}}$ = the number of landslide pixels within the jth subclass of factor $i$

$\mathrm{N}_{\text {total }}=$ the total number of landslide pixels in the area

$\mathrm{A}_{\mathrm{ij}}=$ the total number of pixels of the $\mathrm{jth}$ subclass of the factor

$\mathrm{A}_{\text {total }}=$ the total number of pixels in the study area

FR cannot determine the overall contribution of a factor to landslides. Therefore, the LR model was used to show the association of causal factors with landslides in the form of coefficients (Ayalew and Yamagishi 2005). The main aim of the LR model is to find out the best fitting model which describes the presence of landslides over an area and its relationship with different causal factors (Althuwaynee et al. 2014). It generates coefficients (Eq. 6) for the causal factors. Logit transformation (Eq. 7) gives the probability of the presence of landslides. Finally, the odd ratio (Eq. 8) helps to understand the association of causal factors with the landslides. LR model deals with a dichotomous $(0,1)$ variable. Here, landslide inventory shows the location of landslides or indicates the presence (1) of landslides. The same number of nonlandslide (0) locations were generated randomly using ArcGIS 10.7 for the LR model. Finally, the study had 262 locations (131: landslides and 131: non-landslides), which were the dependent variables, and 15 causal factors were the independent variables. Forward stepwise LR model in IBM SPSS 25 software was used.

$$
Y=\beta_{0}+\beta_{1} X_{1}+\beta_{2} X_{2}+\ldots+\beta_{n} X_{n}
$$

Where,

$\mathrm{Y}=$ Linear combination of landslide causal factors

$\beta_{0}=$ Constant of the equation 

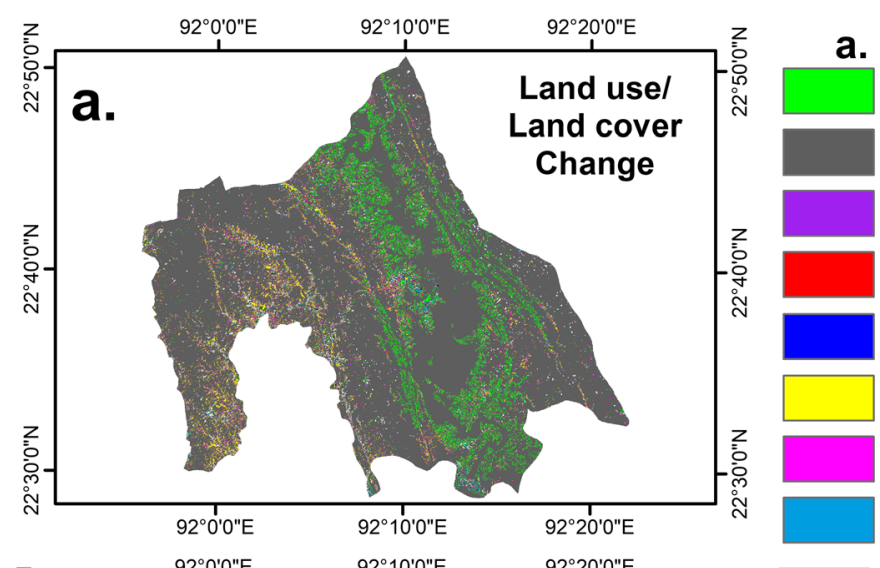

a.

Water-Vegetation

No Change

Water-Bare land

Water-Built up

Vegetation-Water

Vegetation-Bare land

Vegetation-Built up

Built up-Vegetation

高

$92^{\circ} 0^{\prime} O^{\prime \prime E} \quad 92^{\circ} 10^{\prime} O^{\prime \prime E} \quad 92^{\circ} 20^{\prime} O^{\prime \prime}$
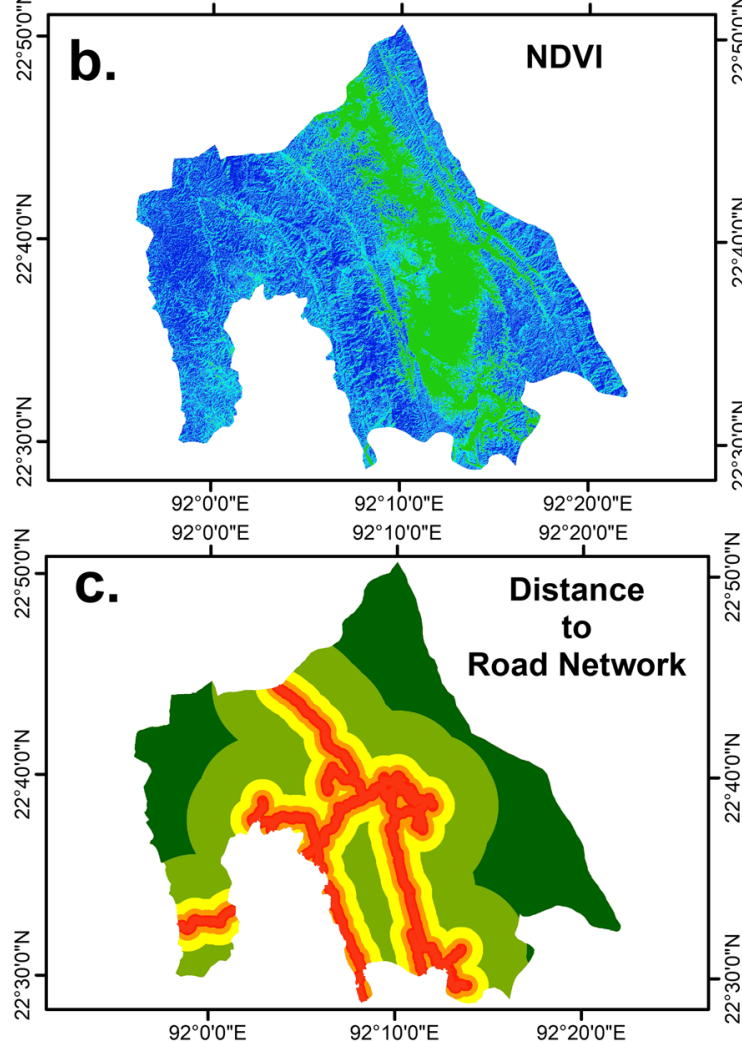

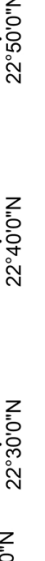

B Bare land-Vegetation

b.

Bare land-Built up

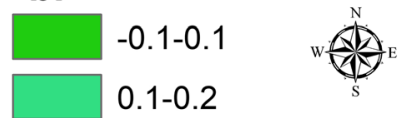

0.2-0.3

0.3-0.4

0.4-0.5

c.

(m)

$0-500=$ Roads

500-100

$1000-2000$

2000-6000

$>6000$

$\begin{array}{lll}5 & 10 & 20\end{array}$

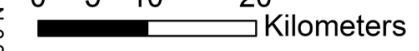

Fig. 5 Landslide Causative Factors: a. Land use/Land cover Change (1998-2018); b. NDVl; c. Distance to Road Networks

$\mathrm{X}_{\mathrm{i}}=$ Causal Factors

$\aleph_{i}=$ Coefficient of the causal factors

$$
\mathrm{P}=\frac{e^{Y}}{1+e^{Y}}
$$

Where,

$\mathrm{P}=$ Probability of the presence of dependent variable

$$
\mathrm{O}=\frac{P}{1-P}
$$

Where,
$\mathrm{O}=$ Odd Ratio (It is the ratio of the probability of absence and presence of landslides)

The size of the landslides did not have a linear relationship with the 15 causal factors. Therefore, we employed the Spearman's rank correlation was used to show the correlations. The Spearman's rank correlation shows the monotonic relationship since it measures the strength and direction of association between two variables (Davis 2002; Laerd Statistics 2018). In this study it is used to check whether the increase or decrease of any causal factor had association with the increase or decrease of the size of landslides. Other than geology, 
land-use land-cover (2018) and land-use land-cover change (1998-2018) were continuous data. So, the study used landslide density instead of categorical input for these three factors. Extract Values to Point tool of ArcGIS 10.7 was used to extract the values of different factors based on the landslide locations. Before that, we converted vector layers of geology to raster layers since all other factors were in raster formats.

\section{Results and discussion}

\section{Characteristics of landslides}

In the study area, flow is the dominant type of landslide (Flow: 53; Slide: 52; Fall: 20 and Complex: 6) followed by slide. Varnes (1978) classification scheme was used in this study. In this scheme, primarily landslides are classified based on the type of movement, and later type of material can be included for detail classification. We considered the type of movement for classification. Most of the landslides occurred near the ChittagongRangamati highway and near to settlements. Debris and materials removed the landslides were cleared very quickly by the local authority and people. It hampered the use of a detailed classification scheme. Excessive rainfall can cause the saturation of the soil, and debris flow can occur in these slopes (Chen et al. 2017). All the landslides were triggered by rainfall, and that explains why the flow was the dominant type of landslides. The slide is the second most dominant type of mass movement after the flow in the study area. From two major types of slides: rotational and transitional slides, this study found that all landslides were rotational slides. Fieldworks revealed that due to excessive rainfall, the surface materials were already removed, and mud or debris flow already occurred. Later water started to enter through the pore spaces and created a zone of weakness above the stable material. This resulted in the rotational slides in the study area. Falls occurred mainly along the Chittagong-Rangamati highway and Kaptai Upazila, where the slope is comparatively steeper. Complex landslides were mainly a combination of a couple of landslides, and in the study area, large landslides $\left(>500 \mathrm{~m}^{2}\right)$ were classified as complex types of landslides. Most of the landslides were small (mean 274. $2 \mathrm{~m}^{2}$ with a standard deviation of $546.1 \mathrm{~m}^{2}$ ). The most massive landslide had an area of $3422.4 \mathrm{~m}^{2}$ while the minimum area of the landslide is $14.6 \mathrm{~m}^{2}$. Around $61 \%$ (Table 1) of the landslides have a size below $100 \mathrm{~m}^{2}$. The frequency density shows that with the increase of size, the number of landslides reduces except for class $\left(500-1000 \mathrm{~m}^{2}\right)$. Generally, more massive landslides can cause more casualties and damages to infrastructures. However, our field investigation suggests that small landslides can cause deaths. In the study area, many people build houses at the foothills. They cut the nearby hills to increase the size of the homestead and to create new dwellings, and thus they damage the slopes. Necessary protective measures were not taken by the government or by the local people to protect them from landslides. Probability density (Table 1 ) indicates that in the study area for landslides with an area between 50 and $100 \mathrm{~m}^{2}$, the probability density is comparatively high. The probability density for $500-1000 \mathrm{~m}^{2}$ area class is lower than the previous area class, although the frequency density is higher than in the last class area.

The probability density (Fig. 6b) decreases with the increase of landslide area, while after a specific size (after $400 \mathrm{~m}^{2}$ ), it starts to increase, and then from $1000 \mathrm{~m}^{2}$ it starts to drop. So, in the study area, the probability of landslides with a size $<50 \mathrm{~m}^{2}$ and $400-1000 \mathrm{~m}^{2}$ are

Table 1 Frequency Density and Probability Density of June 2017 Landslides in Rangamati

\begin{tabular}{llllll}
\hline Area $\left(\mathrm{m}^{2}\right)$ & $\begin{array}{l}\text { Interval } \\
\text { (Area Range) } \\
(\mathrm{i})\end{array}$ & $\begin{array}{l}\text { Number } \\
(\text { Landslides }) \\
(\mathrm{n})\end{array}$ & $\begin{array}{l}\text { Percentage }(\%) \\
(\text { Landslides }) \\
(\mathrm{p})\end{array}$ & $\begin{array}{l}\text { Frequency Density }\left(\mathrm{m}^{-2}\right), \\
\boldsymbol{F d}=\left(\frac{\boldsymbol{n}}{\boldsymbol{i}}\right)\end{array}$ & $\begin{array}{l}\text { Probability Density }\left(\mathrm{m}^{-2}\right), \\
\mathbf{P d}=\left(\frac{\boldsymbol{F d}}{\boldsymbol{t}}\right)\end{array}$ \\
\hline $0-50$ & 50 & 54 & 41.5 & $1.1 \times 10^{0}$ & $8.4 \times 10^{-3}$ \\
$50-100$ & 50 & 27 & 20.8 & $5.4 \times 10^{-1}$ & $4.1 \times 10^{-3}$ \\
$100-200$ & 100 & 13 & 9.9 & $1.3 \times 10^{-1}$ & $9.9 \times 10^{-4}$ \\
$200-300$ & 100 & 5 & 3.9 & $5.0 \times 10^{-2}$ & $3.8 \times 10^{-4}$ \\
$300-400$ & 100 & 7 & 5.4 & $7.0 \times 10^{-2}$ & $5.3 \times 10^{-4}$ \\
$400-500$ & 100 & 5 & 3.9 & $5.0 \times 10^{-2}$ & $3.8 \times 10^{-4}$ \\
$500-1000$ & 500 & 13 & 9.9 & $2.6 \times 10^{-2}$ & $2.0 \times 10^{-4}$ \\
$1000-2000$ & 1000 & 2 & 1.5 & $2.0 \times 10^{-3}$ & $1.5 \times 10^{-5}$ \\
$2000-3000$ & 1000 & 3 & 1.7 & $3.0 \times 10^{-3}$ & $2.3 \times 10^{-5}$ \\
$3000-4000$ & 1000 & 2 & 1.5 & $2.0 \times 10^{-3}$ & $1.5 \times 10^{-5}$ \\
\hline
\end{tabular}

$t$ total number of landslides in the study area 


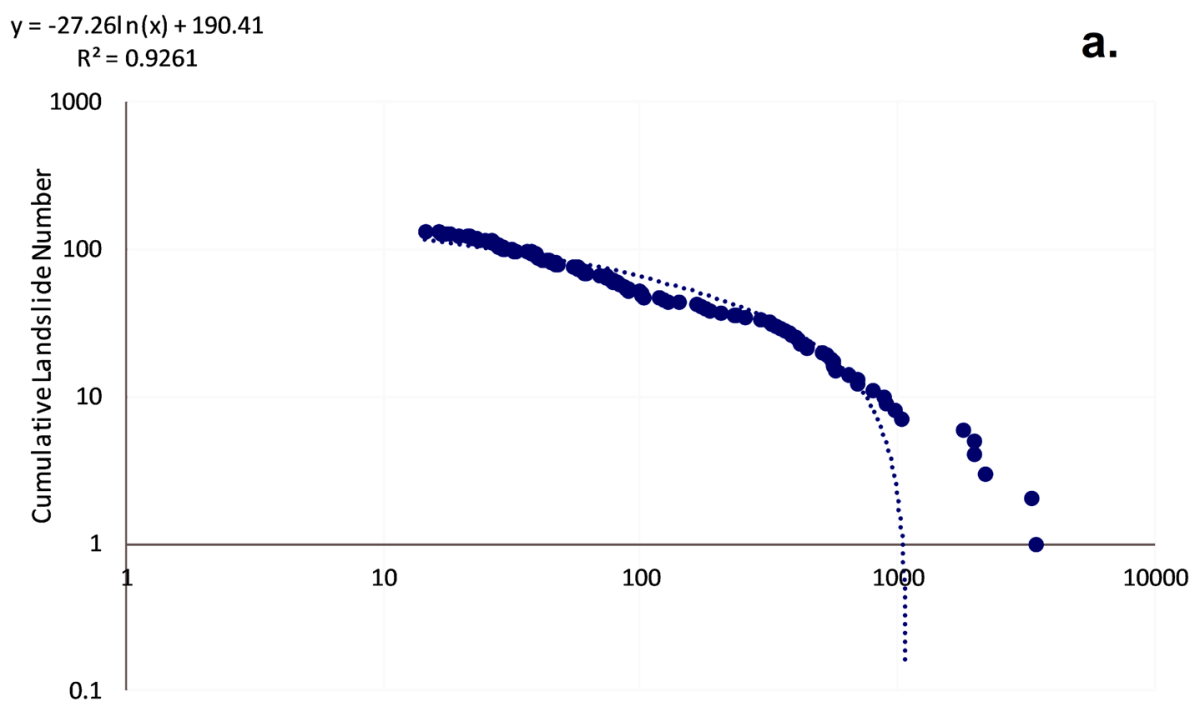

Landslidearea (m2)

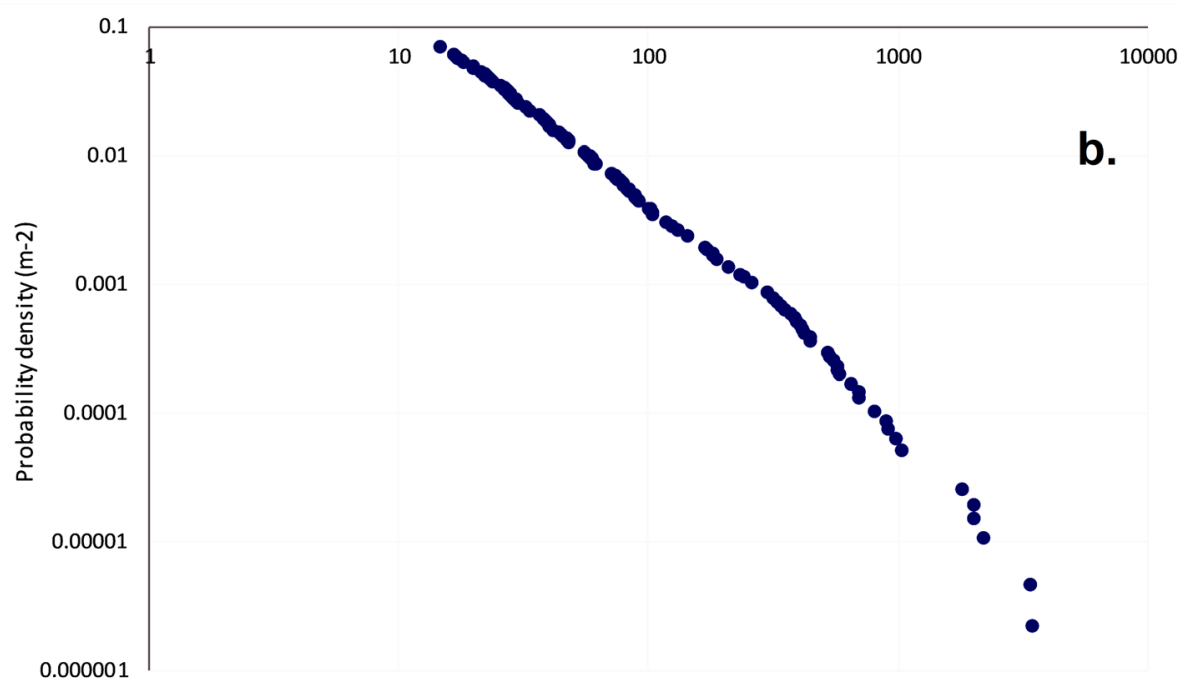

Landslide Area (m2)

Fig. 6 Size Distribution of Landslides in Logarithmic Forms: a. Cumulative Landslide Number and Size Distribution b. Probability Density and Size Distribution

higher than the other area classes. Small landslides $(<50$ $\mathrm{m}^{2}$ ) are abundant in Rangamati Sadar; as mentioned earlier in these areas, people damage the structure of slopes. While more massive landslides $\left(>1000 \mathrm{~m}^{2}\right)$ mainly occurred along the Chittagong Rangamati Highway and in Kaptai Upazilas.

\section{Factors affecting landslides}

In twenty years (1998-2018), there was no land use/land cover change in the study area. $62.06 \%$ of the landslides
(Table 2) occurred in these areas. The rest of the landslides occurred in areas where land use/land cover was transformed from one type to another. From these landslides, $22.05 \%$ occurred in areas where vegetation was transformed into either bare land or built-up areas. In terms of land use/land cover, most of the landslides occurred in land use/land cover type: vegetation (Table 2). Vegetation land use/land cover type includes shrubland, forests, and grassland. $14.87 \%$ of the landslides occurred in bare land, while $14.88 \%$ of the landslides occurred in 
Table 2 Frequency Ratios of Landslide Causal Factors

\begin{tabular}{|c|c|c|c|c|}
\hline Causal Factors & Classes & $\begin{array}{l}\text { Area }(\%), \\
\frac{A_{i j}}{A_{\text {total }}}\end{array}$ & $\begin{array}{l}\text { Landslides (\%), } \\
\frac{\boldsymbol{N}_{i j}}{\boldsymbol{N}_{\text {total }}}\end{array}$ & $\begin{array}{l}\mathrm{FR}, \\
\frac{N_{i j} / N_{\text {total }}}{A_{i j} / A_{\text {total }}}\end{array}$ \\
\hline \multirow[t]{10}{*}{ Aspect } & Flat & 0.00 & 0.00 & 0.00 \\
\hline & North & 17.80 & 5.73 & 0.32 \\
\hline & Northeast & 11.12 & 12.50 & 1.12 \\
\hline & East & 11.17 & 17.19 & 1.54 \\
\hline & Southeast & 10.22 & 12.50 & 1.22 \\
\hline & South & 10.63 & 15.10 & 1.42 \\
\hline & Southwest & 12.37 & 16.67 & 1.35 \\
\hline & West & 11.79 & 6.25 & 0.53 \\
\hline & Northwest & 10.33 & 10.94 & 1.06 \\
\hline & North & 4.58 & 3.13 & 0.68 \\
\hline \multirow[t]{5}{*}{ Elevation (m) } & $0-50$ & 47.64 & 23.96 & 0.50 \\
\hline & $50-100$ & 34.34 & 50.00 & 1.46 \\
\hline & $100-170$ & 10.71 & 21.88 & 2.04 \\
\hline & $170-274$ & 5.51 & 4.17 & 0.76 \\
\hline & $>274$ & 1.81 & 0.00 & 0.00 \\
\hline \multirow[t]{5}{*}{ Slope $\left(^{\circ}\right)$} & $0-5$ & 25.71 & 8.85 & 0.34 \\
\hline & $5-10$ & 30.28 & 25.00 & 0.83 \\
\hline & $10-16$ & 24.32 & 28.13 & 1.16 \\
\hline & $16-24$ & 14.91 & 28.13 & 1.89 \\
\hline & $24-59$ & 4.78 & 9.90 & 2.07 \\
\hline \multirow[t]{5}{*}{ SPI } & $2-5$ & 22.19 & 15.63 & 0.70 \\
\hline & $5-7$ & 38.22 & 44.79 & 1.17 \\
\hline & $7-8$ & 28.49 & 32.29 & 1.13 \\
\hline & $8-11$ & 8.69 & 6.77 & 0.78 \\
\hline & $>11$ & 2.43 & 0.52 & 0.21 \\
\hline \multirow[t]{5}{*}{ TWI } & $6-10$ & 48.98 & 68.23 & 1.39 \\
\hline & $10-12$ & 26.20 & 25.52 & 0.97 \\
\hline & $12-15$ & 12.36 & 5.21 & 0.42 \\
\hline & $15-19$ & 11.41 & 1.04 & 0.09 \\
\hline & $>19$ & 1.05 & 0.00 & 0.00 \\
\hline \multirow[t]{3}{*}{ Plan Curvature } & Convex & 41.09 & 43.75 & 1.06 \\
\hline & Concave & 50.52 & 42.53 & 1.19 \\
\hline & Flat & 16.38 & 5.73 & 0.35 \\
\hline \multirow[t]{3}{*}{ Profile Curvature } & Convex & 41.12 & 45.83 & 1.11 \\
\hline & Concave & 44.71 & 50.00 & 1.12 \\
\hline & Flat & 14.17 & 4.17 & 0.29 \\
\hline \multirow[t]{5}{*}{ NDVI } & $-0.1-0.1$ & 17.99 & 1.59 & 0.09 \\
\hline & $0.1-0.2$ & 6.98 & 8.47 & 1.21 \\
\hline & $0.2-0.3$ & 20.42 & 36.51 & 1.79 \\
\hline & $0.3-0.4$ & 31.87 & 34.92 & 1.10 \\
\hline & $0.4-0.5$ & 22.74 & 18.52 & 0.81 \\
\hline \multirow[t]{2}{*}{ Distance to Road Network (m) } & $0-500$ & 10.50 & 72.49 & 6.90 \\
\hline & $500-1000$ & 17.01 & 14.81 & 0.87 \\
\hline
\end{tabular}


Table 2 Frequency Ratios of Landslide Causal Factors (Continued)

\begin{tabular}{|c|c|c|c|c|}
\hline Causal Factors & Classes & $\begin{array}{l}\text { Area }(\%), \\
\frac{A_{i j}}{A_{\text {total }}}\end{array}$ & $\begin{array}{l}\text { Landslides (\%), } \\
\frac{\boldsymbol{N}_{i j}}{\boldsymbol{N}_{\text {total }}}\end{array}$ & $\begin{array}{l}\mathrm{FR}, \\
N_{i j} / N_{\text {total }} \\
A_{i j} / A_{\text {total }}\end{array}$ \\
\hline & $1000-2000$ & 23.04 & 8.99 & 0.39 \\
\hline & $2000-6000$ & 42.82 & 3.70 & 0.09 \\
\hline & $>6000$ & 6.63 & 0.00 & 0.00 \\
\hline \multirow[t]{5}{*}{ Distance to Drainage Network (m) } & $0-500$ & 8.01 & 12.70 & 1.59 \\
\hline & $500-1000$ & 7.99 & 16.40 & 2.05 \\
\hline & $1000-2000$ & 16.14 & 21.16 & 1.31 \\
\hline & $2000-5000$ & 50.86 & 34.92 & 0.69 \\
\hline & $>5000$ & 17.01 & 14.81 & 0.87 \\
\hline \multirow[t]{5}{*}{ Distance to Fault Lines (m) } & $0-500$ & 1.88 & 4.76 & 2.54 \\
\hline & $500-1000$ & 6.88 & 5.29 & 0.77 \\
\hline & $1000-5000$ & 45.27 & 66.14 & 1.46 \\
\hline & $5000-10,000$ & 38.65 & 23.81 & 0.62 \\
\hline & $>10,000$ & 7.33 & 0.00 & 0.00 \\
\hline \multirow[t]{5}{*}{ Rainfall (mm) } & $2370-2450$ & 32.16 & 11.9 & 0.37 \\
\hline & $2450-2525$ & 24.40 & 63.69 & 2.61 \\
\hline & $2525-2607$ & 21.11 & 15.41 & 0.73 \\
\hline & $2607-2707$ & 9.78 & 9.00 & 0.92 \\
\hline & $>2707$ & 12.55 & 0.00 & 0.00 \\
\hline \multirow[t]{8}{*}{ Geology } & Dihing and Dupi Tila Formation & 4.65 & 19.07 & 4.10 \\
\hline & Boka Bil Formation & 28.92 & 30.41 & 1.05 \\
\hline & Bhuban Formation & 8.97 & 16.49 & 1.84 \\
\hline & Tipam Sandstone & 12.41 & 27.84 & 2.24 \\
\hline & Valley Alluvium and Colluvium & 0.46 & 0.00 & 0.00 \\
\hline & Dupi Tile Formation & 14.73 & 3.61 & 0.25 \\
\hline & Lake & 26.46 & 0.00 & 0.00 \\
\hline & Girujan Clay & 3.41 & 2.58 & 0.76 \\
\hline \multirow[t]{4}{*}{ Land use/Landcover } & Vegetation & 73.60 & 70.26 & 0.95 \\
\hline & Waterbodies & 18.40 & 0.00 & 0.00 \\
\hline & Bare land & 5.38 & 14.87 & 2.77 \\
\hline & Built up & 2.62 & 14.88 & 5.67 \\
\hline \multirow[t]{11}{*}{ Land use Change } & Water-Vegetation & 5.31 & 2.05 & 0.39 \\
\hline & Water-Bare Land & 0.70 & 0.51 & 0.73 \\
\hline & Water-Built up & 0.25 & 0.51 & 2.02 \\
\hline & Vegetation-Water & 0.00 & 0.00 & 0.00 \\
\hline & Vegetation-Bare land & 3.54 & 12.82 & 3.62 \\
\hline & Vegetation-Built up & 1.74 & 9.23 & 5.31 \\
\hline & Built up- Vegetation & 0.81 & 1.54 & 1.91 \\
\hline & Built up-Bare land & 0.23 & 0.51 & 2.20 \\
\hline & Bare land-Vegetation & 2.09 & 7.18 & 8.65 \\
\hline & Bare land- Built up & 0.45 & 3.59 & 3.44 \\
\hline & No Change & 84.88 & 62.06 & 0.73 \\
\hline
\end{tabular}


built-up areas. Bhuban and Boka Bil formations accounted for $46.9 \%$ of the landslides in the study area. Due to the presence of alteration of sandstone and shale, these two geological formations are susceptible to landslides. The Tipam Sandstone formation is comprised of sheets of sand and formed near the rivers (Ahmed and Dewan 2017). 27.84\% of the landslides occurred in the Tipam Sandstone areas. In this formation, the elevation is comparatively low, and the slope is gentle. It indicates that other factors may have more impacts on the occurrences of landslides than geology. In the study area, the highest slope is $58.58^{\circ} .91 \%$ of the landslides occurred in areas where slope ranged from 5 to $24^{\circ}$. Generally, the steeper the slope, the harder the structure of the rock. Comparatively, harder rocks protect the slope from failure (Yilmaz 2009). In the study area, all the landslides occurred within $274 \mathrm{~m}$ elevation (Table 2), from which $50 \%$ occurred in areas where elevation ranged from 50 to $100 \mathrm{~m}$. Like slope after certain elevation landslides were rare due to rock structure. There is not much variation (ranges from 2370 to $2810 \mathrm{~mm}$ ) in annual rainfall in the study area. Therefore, most of the landslides (63.69\%) (Table 2) occurred where annual rainfall ranged from 2450 to $2525 \mathrm{~mm}$. Landslide occurrences had an inverse relationship with the distance to the road network (Table 2). Most of the landslides (96.29\%) occurred within $2000 \mathrm{~m}$ distance to the roads. Like the distance to the road networks, landslides had an inverse relationship with the distance to the drainage network (Table 2). Normalized Difference Vegetation Index (NDVI) value ranges from - 0.1-0.5 (Table 2) in the study area. Negative values of the NDVI (values approaching -1) corresponds to water, while values near to zero $(-0.1$ to 0.1$)$ generally correspond to barren areas. Low, positive values mean shrub and grassland (approximately 0.2 to 0.4 ), while high values approaching 1 designate temperate and tropical rainforests. Based on the NDVI (0.2$0.5)$, most of the landslides (89.95\%) occurred in shrub and grassland covered areas. While $8.47 \%$ of the landslides occurred in built-up areas or bare lands where NDVI values ranged from 0.1-0.2. As discussed before, most of the landslides occurred within $2000 \mathrm{~m}$ distance to the road network, and these areas are mainly close to vegetation. That is why this type of land use and land cover accounts for a higher percentage of landslides. Most of the landslides occurred in areas where TWI ranges from 6 to 10 (Table 2). Very few landslides occurred in areas with higher TWI values $(>12)$. TWI shows the soil moisture distribution and high TWI values indicate higher water accumulation. During heavy rainfall, these areas become highly susceptible to landslides (Yilmaz 2009). 44.79\% (Table 2) of the landslides occurred in areas where SPI value ranges between 5 and 7. From the above discussion, we cannot point out which factors create conducive conditions for landslides. Some of the findings are opposite to the common knowledge about the factors of landslides. Landslides may occur in one class or category of the causal factor, for example, vegetation; a land-use land-cover type experienced, most of the landslides in the study area. Still, it does not necessarily mean that areas under vegetation are highly susceptible. That is why we used FR to understand the effects of different causal factors on the occurrences of landslides. All types of land use/land cover change (Table 2) had a higher FR value except water bodies to vegetation and bare land. It indicates that water bodies were filled up to create land, and as they are flatlands, no landslide occurred there. Vegetation to built-up area and vegetation to bare land had very high FR (5.31 and 3.62 respectively) values the removal of vegetation and development activities in the bare land damaged the slope structure and created a conducive condition for landslides. The built-up area had an FR value of 5.67, while bare land had 2.77 (Table 2). Therefore, these two-land use/land cover types are highly susceptible to landslides. In Rangamati Sadar, slums and low-quality housing were built near the hills. People cut the vegetation on the slopes and the foothills, which damage the slope structure. It also reduces the water retention capacity of the soil. Larger landslides occurred in areas under rubber plantation. Largest landslides (> $3000 \mathrm{~m}^{2}$ ) occurred in a rubber garden where natural forests were cleared, and new rubber trees were planted. The roots of the newly planted rubber trees did not go deep, and the coverage was not as dense as the natural forest. Therefore, it created a conducible condition for landslides. Excessive rainfall started from June 7, 2017, triggered the landslides. Before the landslides, the study area experienced around one-third of its annual rainfall within 5 days (Haque et al. 2018). $510 \mathrm{~mm}$ (20 in.) rainfall occurred in southeastern Bangladesh between June 12 and 14 when landslides triggered by a heavy downpour (Prothom Alo 2017). Like the percentage of landslides (Table 2), the Dihing and Dupi Tila formation had higher FR value (4.10), and the Tipam Sandstone and Bhuban Formation have higher FR values as well (2.24 and 1.84 respectively).

Slope (Table 2) shows a different pattern from the percentage of landslides as slope $>16^{\circ}$ had a higher probability of landslides $(F R>1.89)$. (Table 2) shows that elevation class $100-170 \mathrm{~m}$ had FR value of 2.04 , which means that the areas within this elevation had high susceptibility. (Table 2) Distance to road and distance to river networks show the same pattern as the percentage. It shows that areas near to the road and drainage networks are more prone to landslides. Annual rainfall, SPI, and TWI (Table 2) had the same pattern as the percentage (Table 2). Built-up area and bare land were highly 
prone to landslides as FR of NDVI (Table 2) show that NDVI value ranges from 0.1 to 0.3 have $F R>1.21$. From the above discussion, it is evident that land use/ land cover change and some land-use types and anthropogenic activities like road construction create conducive conditions for landslides in the study area.

In the stepwise forward process in each of the steps, one conditioning factor is added and checked whether Pseudo $\mathrm{R}$ square value (Table 3 ) gets a significant increase. Model summary of the six steps (Table 3 and Table 4) shows that in step 6, the Nagelkerke R square value is 0.679 , and in step 7 , it does not get a significant increase and thus the stepwise process stops.

Coefficients (B) (Table 4) for distance to road network $(B=0.44)$ elevation, distance to drainage network $(B=$ $0.76)$, SPI $(\beta=-1.06)$, land use $/$ land cover $(\beta=0.70)$ and slope $(\beta=1.05)$ are significant. In the FR model, it was found that a subclass of different factors had an association with the landslides. We did not identify the overall contribution of the factor, and the LR model helped in this purpose. It also indicates that some factors sub-class had an association with landslides, but as a factor, they did not. The odds ratio (Table 4) for slope (3.78), distance to drainage (1.96), and elevation (1.47) were high. The odds ratio for slope is 3.78 , which indicates an area with a high or steeper slope had a $278 \%$ higher chance of landslides than the areas with a low or gentle slope. In the FR model, it was found that up to a certain slope, the association of slope with landslides increases, and then it decreases. But in the LR model, the coefficient and odd ratio cannot determine this extent. It justifies the use of using both FR and LR models in the study. The odd ratio for distance to drainage network was 1.96 , and it means that with the increase of distance to drainage the chance of landslides increases by $96 \%$. In the FR model, the same pattern was found because FR values increased with the increase of distance to the drainage network.

From 15 factors, (Table 5) slope $(\rho=0.182)$, rainfall $(\rho=0.522)$, elevation $(\rho=0.235)$, distance to drainage $(\rho=0.261)$, distance to the road $(\rho=-0.26)$ and geology $(\rho=0.221)$ had a significant rank correlation with the size of landslides. Higher frequency ratio value for different land use/land cover class and land use/land cover

Table 3 Model Summary for Six Steps of LR Model

\begin{tabular}{lll}
\hline Step & -2log Likelihood & Nagelkerke R Square \\
\hline 1 & 347.67 & 0.57 \\
2 & 325.09 & 0.61 \\
3 & 304.86 & 0.64 \\
4 & 296.35 & 0.65 \\
5 & 286.41 & 0.67 \\
6 & 280.99 & 0.68 \\
\hline
\end{tabular}

Table 4 Results of Logistic Regression

\begin{tabular}{|c|c|c|c|c|c|c|c|}
\hline & Conditioning Factors & B & S.E. & Wald & $\mathrm{df}$ & Sig. & $\operatorname{Exp}(B)$ \\
\hline \multirow[t]{7}{*}{ Step 6} & Distance to Drainage & 0.76 & 0.26 & 8.568 & 1 & 0.003 & 1.96 \\
\hline & Elevation & 0.50 & 0.14 & 12.877 & 1 & 0.000 & 1.47 \\
\hline & Land use/Land Cover & 0.70 & 0.15 & 20.939 & 1 & 0.000 & 1.08 \\
\hline & Distance to Road & 0.44 & 0.05 & 87.428 & 1 & 0.000 & 0.82 \\
\hline & Slope & 1.05 & 0.23 & 20.476 & 1 & 0.000 & 3.78 \\
\hline & SPI & -1.06 & 0.45 & 5.351 & 1 & 0.021 & .01 \\
\hline & Constant & -4.146 & 0.12 & 12.155 & 1 & 0.000 & .016 \\
\hline
\end{tabular}

change indicates the influence of land use and the land cover on landslide occurrence. Still, they did not have a significant correlation with the size of landslides. Geology, land use/land cover, and land use/land cover change were categorical variables, and the study used the density of landslides as input variables for correlation analysis. So, it did not show the direct impact of these factors. Other factors were continuous variables, and direct correlations with landslide sizes were computed.

\section{Consequences of landslides}

Landslides pose a severe physical and environmental threat to the communities living in the landslide-prone areas (Auflič et al. 2018). Loss of life is the most significant socio-economic impact of landslides, and another essential effect is the loss of livelihood. This study investigated whether June 13, 2017, landslides had any impact on the livelihood of the local people. Jhum cultivation $(45.8 \%)$ is the main occupation of the local people, followed by business (12.5\%) and service (18.3\%). Jhum cultivation is a common agricultural practice in $\mathrm{CHA}$, in which farmers clear a slope and plant crops in one season, and next season keep it, fellow. To clear the slope, they generally burn the forest. This study shows that during June, after the landslides, $54.55 \%$ (Fig. 7) of the jhum cultivators became jobless. A social survey of the study revealed that landslides affected their agricultural land, and they lost crops as well. In the study area, only $2 \%$ of the people are involved in transportation sectors (mentioned as drivers in Fig. 7), and they were the most affected community. Due to landslides, most of the roads

Table 5 Spearman's Rank Correlation Between Different Factors and Size of the Landslides

\begin{tabular}{lllllllll}
\hline & 1 & 2 & 3 & 4 & 5 & 6 & 7 & 8 \\
\hline$\rho$ & $0.18^{*}$ & 0.15 & -0.09 & $0.52^{*}$ & 0.10 & $0.24^{* *}$ & -0.04 & $0.26^{*}$ \\
& $\mathbf{9}$ & $\mathbf{1 0}$ & $\mathbf{1 1}$ & $\mathbf{1 2}$ & $\mathbf{1 3}$ & $\mathbf{1 4}$ & $\mathbf{1 5}$ & \\
\hline & -0.05 & $0.22^{*}$ & -0.03 & 0.22 & 0.12 & 0.11 & -0.26 & \\
\hline
\end{tabular}

$\boldsymbol{\rho}=$ Spearman's Rank Correlation; ${ }^{*}=P$ value is Less that $0.05 ;{ }^{* *}=\mathrm{P}$ value is less than 0.01. 1 = Slope; $2=\mathrm{SPI} ; 3=\mathrm{TWl} ; 4=$ Rainfall; $5=\mathrm{NDVl} ; 6=$ Elevation; $7=$ Distance to the Road Network; $8=$ Distance to Drainage Network; $9=$ Landuse land-cover Change; $10=$ Geology; 11 = Land-use land-cover, $12=$ Aspect; $13=$ Plan Curvature; $14=$ profile curvature; $15=$ Distance to Fault Lines 


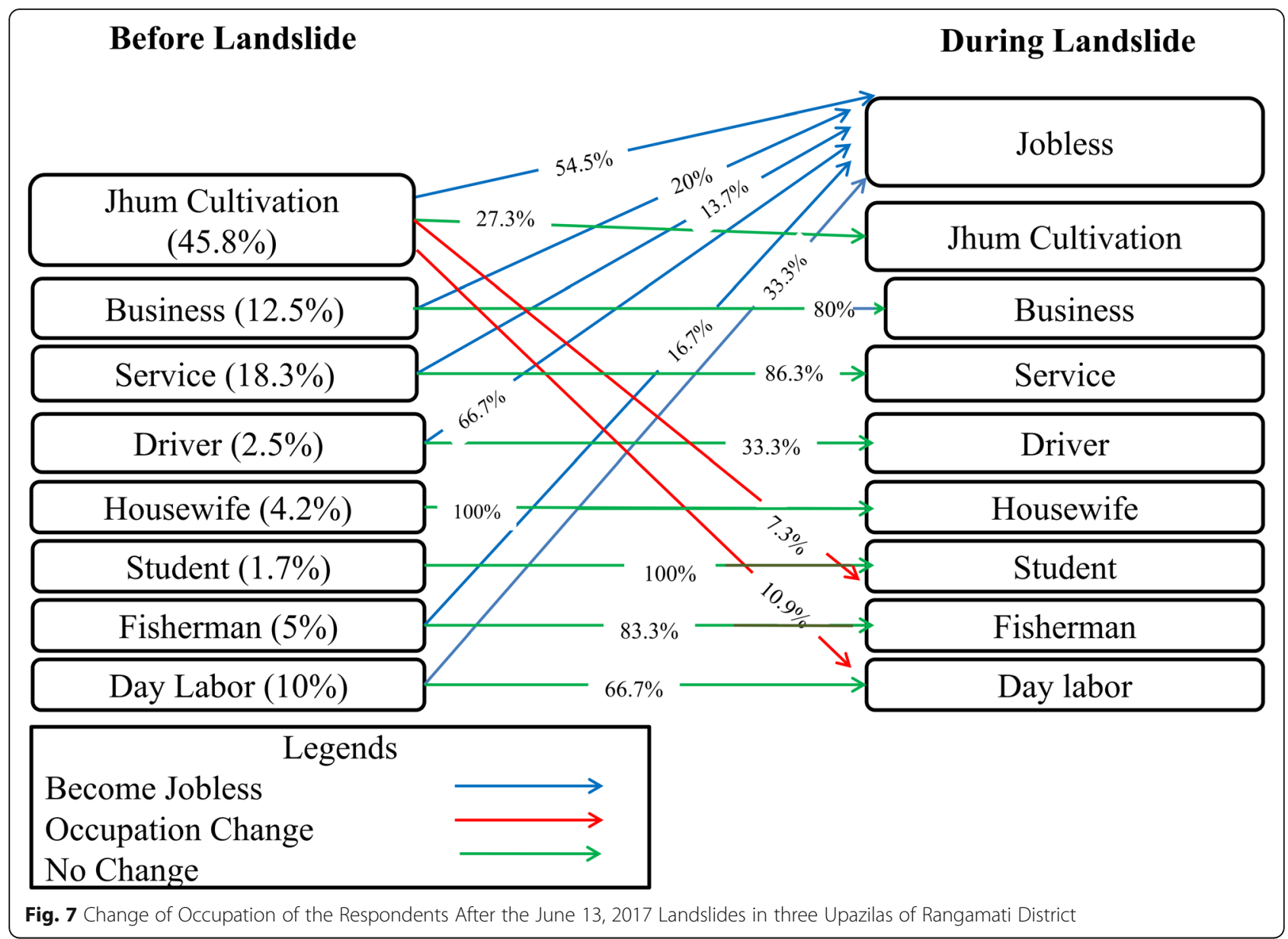

were closed for several days, and therefore, they become jobless.

The present study collected the monthly income before (May), during (June) and after (July) landslides. The fluctuation of income for 3 months would give an idea of how the landslides affected the income of local people. For all the occupations, monthly income (Table 6) dropped during June when landslides occurred. Some jobs, like business and transportation, recovered soon. After the landslides, the government cleared the debris from the roads and repaired the streets. As a result of that, the transportation system returned to its original state very soon. The business and transportation sector were affected the most as people involved in these two activities lost $19.1 \%$ and $27.9 \%$, respectively. As mentioned earlier, they recovered very soon while people engaged in jhum cultivation failed to regain their earnings, and the earnings reduced by $12.2 \%$.

The mean monthly incomes (Table 7) for different jobs before landslides were significantly different from the mean monthly incomes of during and after landslides for all the jobs except jhum cultivation and

Table 6 Monthly Income of the Landslides Affected People before (May), During (June) and After (July) Landslides

\begin{tabular}{llll}
\hline Occupation & $\begin{array}{l}\text { Monthly Income (\$) } \\
\text { (May) }\end{array}$ & Monthly Income (\$) (June) & Monthly Income (\$) (July) \\
\hline Day Laborer & 112.7 & 92.9 & 110.4 \\
Business & 313.7 & 253.9 & 265.3 \\
Service & 322.7 & 270.5 & 243.3 \\
Jhum Cultivation & 140.6 & 123.4 & 122.1 \\
Fishing & 123.4 & 116.7 & 108.8 \\
Driving & 130.6 & 94.1 & 133.1 \\
Others & 182.0 & 163.7 & 170.0 \\
\hline
\end{tabular}


Table 7 Paired Samples Test for Detecting Significant Differences in Income

\begin{tabular}{llll}
\hline Occupation & Pair Type & t score & Significance (2-tailed) \\
\hline Business & Before-During & 7.6 & 0.000 \\
\multirow{2}{*}{ Service } & Before- After & 27.5 & 0.000 \\
& Before-During & 9.1 & 0.000 \\
Jhum Cultivation & Before- After & 12.2 & 0.161 \\
& Before-During & 1.4 & 0.000 \\
Fishing & Before- After & 4.6 & 0.026 \\
& Before-During & 1.1 & 0.000 \\
Driving & Before- After & 3.7 & 0.000 \\
& Before-During & 7.8 & 0.844 \\
Other & Before- After & -0.2 & 0.000 \\
& Before-During & 4.5 & 0.001 \\
& Before- After & 3.3 & 0.000 \\
\hline
\end{tabular}

transportation. For jhum cultivations, before and during landslides, monthly payments were not significantly different, but after landslides during July, monthly income reduced significantly. It indicates the long-term effects of landslides and jhum cultivators were not able to recover from the loss they suffered from the landslides. Fishing has the same pattern, and we can say that landslides did not pose an impact on primary activities just after the occurrence, but in the long run, landslides had effects. On the other hand, people who are involved in transportation sectors (mainly drivers of local transportation) recovered very quickly as the income before and after are significantly different, and (Table 6) shows that the mean income increased.

\section{Conclusion}

This research investigates the characteristics, causes, and consequences of June 13, 2017, landslides in Rangamati Sadar, Kaptai, and Kawkhali Upazilas of the Rangamati district. Analyses of the types and the size distribution helped to understand the characteristics of the landslides. FR and LR models gave an idea about the causes of landslides, while the pre-event and post-event income analysis of the local people revealed the consequences of landslides. Flow and rotational slides account for around $80 \%$ of the landslides of the study area. Excessive rainfall in a short period causes the flow and rotational slides in the study area. On the other hand, the results of the size distribution analysis demonstrate that most of the landslides were shallow and small $\left(<100 \mathrm{~m}^{2}\right)$ in size. Smaller landslides mainly occurred in areas near to settlements and roads. Comparatively, massive landslides $(>2000$ $\mathrm{m}^{2}$ ) happened in the plantation agriculture fields. These findings of types and size of landslides can be linked with the recent land use/land cover change. Trees in the plantation agriculture fields are not capable enough to protect the top surface from erosion and disintegration, which in turn help in the initiation of massive landslides. These landslides bring economic consequences since it destroys the whole plantation filed. On the other hand, comparatively smaller landslides can be fatal in the study area since Rangamati Sadar Upazila low-income people build slums near the foothills. Small landslides can destroy these dwellings and cause fatality very easily. This study shows the importance of carrying out more research to reveal the impact of land use/land cover change on landslides. Results of the FR and LR methods highlight that causal factors like slope, distance to the drainage and road networks, land use/land cover, and land use/land cover change are the most critical factors that control the occurrences of landslides. This study provides the results of Spearman's rank correlation between the dimension and causal factors of landslides. These findings show that the same set of causal factors does not necessarily control occurrences and sizes of landslides. Generally, most of the landslide related studies try to find out the relationship between causal factors and landslide occurrences while present research deals with both occurrence and dimensions. It gives a broader understanding of landslide of the study area.

Our study has revealed the consequences of landslides on the local economy, while research on consequences of landslides are very rare in CHA (Sultana 2020). Landslides hampered the primary economic activities, including fishing and jhum cultivation. It has long term effects on primary economic activities since both land and crops are destroyed. One of the exciting findings of this research is that secondary and tertiary activities are not affected for a long time compared to primary economic activities. However, these two types of economic activities are affected immediately after the landslides. Most of the secondary and tertiary financial workers get their payment on a day to day basis in the study area; therefore, they are affected immediately.

Our study is reasonably consistent with the study of Sifa et al. (2019). However, their study used two bivariate methods: frequency ratio and weight of evidence methods for landslide susceptibility mapping of the study area. On the other hand, our research used a bivariate: FR and a multivariate approach: $L R$ to find out the causes of landladies. Moreover, our study used field investigation-based landslide inventory, while Sifa et al. (2019) used remote sensing-based landslide inventory. Nevertheless, the results of FR methods are consistent in both the studies.

The findings of our study are essential for the policymakers, and urban and regional planners to formulate policies that would mitigate the problems caused by the landslides in the study area. Policymakers must think about the lower-income people living in the foothills. 
These people should be relocated somewhere else of necessary precautionary measures should be taken so that landslide cannot damage their houses and cause fatalities. Local authorities should make the local people aware of the danger of landslides as well as the causes so that they will not damage the slope instability while increasing the size of their homesteads. By providing the results, the present study has made the policymakers and the plantation farm owners aware of the impacts of plantation agriculture on landslides. Indiscriminate and unplanned land use/land cover change will create more problems; the economic loss and human fatalities will surpass the short financial gains of plantation farming. Therefore, this study recommends that a long-term land use/land cover planning is essential for the study area.

The main limitation of this study is that field investigation mainly covered accessible areas for landslide inventory mapping. Many landslides may have occurred in the inaccessible areas. Nevertheless, our study gives an idea of the characteristics of landslides in the study area. Future studies can integrate both filed based and remote sensing-based landslide inventory for a detailed analysis. In the socio-economic survey, this study relied on the response of the respondents. We did not have any other source to verify that other than talking to the local political leaders and government officials. This study collected the size of landslides and but not the amount of mass displaced. Future studies can use remote sensing techniques to measure the displaced mass, and it would give a better idea about the characteristics of landslides.

\section{Acknowledgments}

Not applicable.

\section{Authors' contributors}

All authors participated in the field investigation. Abedin, J and Rabby, YW drafted the manuscript. All authors have read and approved the final manuscript.

\section{Funding}

Not applicable.

\section{Availability of data and materials}

Landslide inventory of the study area and other data can be shared upon request.

\section{Competing interests}

The authors declare that they have no competing interests.

\section{Author details}

'Department of Geography and Environment, University of Dhaka, Dhaka 1000, Bangladesh. ${ }^{2}$ Department of Geography, University of Tennessee, Knoxville, Burchfiel Geography Building, Knoxville, TN 37996-0925, USA.

Received: 11 November 2019 Accepted: 8 August 2020

Published online: 15 August 2020

\section{References}

Ahmed B (2015a) Landslide susceptibility mapping using multi-criteria evaluation techniques in Chittagong metropolitan area, Bangladesh. Landslides 12: 1077-1095
Ahmed B (2015b) Landslide susceptibility modeling applying user-defined weighting and data-driven statistical techniques in Cox's Bazar municipality, Bangladesh. Nat Hazards 79(3):1707-1737. https://doi.org/10.1007/s11069015-1922-4

Ahmed B, Dewan A (2017) Application of bivariate and multivariate statistical techniques in landslide susceptibility modeling in Chittagong City Corporation, Bangladesh. Remote Sens 9(4):304. https://doi.org/10.3390/ rs9040304

Althuwaynee OF, Pradhan B, Park HJ, Lee JH (2014) A novel ensemble bivariate statistical evidential belief function with knowledge based analytical hierarchy process and multivariate statistical logistic regression for landslide susceptibility mapping. Catena 114:21-36

Anderson JR (1976) A land use and land cover classification system for use with remote sensor data (Vol. 964). US Government Printing Office.

Auflič MJ, Kumelj S, Peternel T, Jež J (2018) Understanding of landslide risk through learning by doing: case study of Koroška Bela community. Landslides, Slovenia

Ayalew L, Yamagishi H (2005) The application of GIS- based logistic regression for landslide susceptibility mapping in the Kakuda- Yahiko Mountains, Central Japan. Geomorphology 65:15-31

Bangladesh Bureau of Statistics (2012) Population and housing census 2011: national report. Bangladesh bureau of statistics, Dhaka, Bangladesh. http:// www.bbs.gov.bd/WebTestApplication/userfiles/Image/Census2011/ Chittagong/Rangamati/Rangamati\%20at\%20a\%20glance.pdf. Accessed 11 Aug 2020.

Banglapedia (2014) Climate. Banglapedia: National Encyclopedia of Bangladesh. Asiatic Society of Bangladesh, Dhaka, Bangladesh

Banglapedia (2015) Landslide. Banglapedia: National Encyclopaedia of Bangladesh. Asiatic Society of Bangladesh

Bui DT, Lofman O, Revhaug I, Dick O (2011) Landslide susceptibility analysis in the Hoa Binh province of Vietnam using statistical index and logistic regression. Nat Hazards 59:1413-1444. https://doi.org/10.1007/s11069-011-9844-2

Chen WC, Chen H, We LW, Lin GW, Lida T, Yamada R (2017) Evaluating the susceptibility of landslide landforms in Japan using slope stability analysis: a case study of the 2016 Kumamoto earthquake. Landslides 14:1793-1801 https://link.springer.com/content/pdf/10.1007/s10346-017-0872-1.pdf. Access 23 June 2020

Davis JC (2002) Statistics and data analysis in geology (Vol. 646). Wiley, New York

Dewan AM, Yamaguchi Y (2008) Using remote sensing and GIS to detect and monitor land use and land cover change in Dhaka metropolitan of Bangladesh during 1960-2005. Environ Monit Assess 150:237-249. https:// doi.org/10.1007/s10661-008-0226-5

ESRI (2017) ArcGIS desktop. Near. Redlands, CA: Environmental Systems Research Institute. 2017. Web. March 20. 2018

Ferdous L, Kafy A A, Roy S, Chakma R (2017) An analysis of Causes, Impacts and Vulnerability Assessment for Landslides Risk in Rangamati District, Bangladesh. In International Conference on Disaster Risk Mitigation., Dhaka, Bangladesh. http://www.bip.org.bd/SharingFiles/201805080735531.pdf. Accessed 11 Aug 2020.

Guha-Sapir D, Vos F, Below R, Ponserre S (2012) Annual disaster statistical review 2011: the numbers and trends. Centre for Research on the Epidemiology of Disasters (CRED). http://lib.riskreductionafrica.org/bitstream/handle/123456 789/1141/annual\%20disaster\%20statistical\%20review\%202011.\%20the\%2 Onumbers\%20and\%20trends.pdf?sequence=1. Accessed 11 Aug 2020.

Guzzetti F, Mondini AC, Cardinali M, Pepe A, Cardinali M, Zeni G, Reichenbach P, Lanari R (2012) Landslide inventory maps: new tools for an old problem. Earth-Sci Rev 112:42-66

Haque DME, Sifa S, Mahmud T, Tarin MA (2018) Landslide susceptibility assessment based on satellite image processing and bi-variate statistical modeling for Rangamati district, Bangladesh. Bangladesh J Physics 23 \& 24: 93-106

Harris PM, Ventura SJ (1995) The integration of geographic data with remotely sensed imagery to improve classification in an urban area. Photogramm Eng Remote Sens 61(8):993-998

Islam, MA, Islam MS, Islam T (2017a). Landslides in Chittagong hill tracts and possible measures. In International Conference on Disaster Risk Mitigation, Dhaka, Bangladesh, September 23-24, Dhaka. https://www.researchgate.net/ profile/Mohammad_Islam28/publication/320014168_LANDSLIDES_IN_ CHITTAGONG_HILL_TRACTS_AND_POSSIBLE_MEASURES/links/59c86a80aca2 72c71bc7f50d/LANDSLIDES-IN-CHITTAGONG-HILL-TRACTS-AND-POSSIBLEMEASURES.pdf. Accessed 11 Aug 2020. 
Islam MA, Murshed S, Kabir SMM, Faraz AH, Gazi MY, Jahan I, Akhter SH (2017b) Utilization of open source spatial data for landslide susceptibility mapping at Chittagong District of Bangladesh —an appraisal for disaster risk reduction and mitigation approach. Int J Geosci 8:577-598. https://doi.org/10.4236/ijg.84031

Jensen IR, Ramsey EW (1987) Inland wetland change detection using aircraft MSS data. Photogramm Eng Remote Sens 53(5):521-529

Laerd Statistics (2018) Spearman's Rank-Order Correlation. https://statistics.laerd. com/statistical-guides/spearmans-rank-order-correlation-statistical-guide.php. Accessed 23 June 2020

Li C, Wang J, Wang L, Hu L (2014) Gong P Comparison of classification algorithms and training sample sizes in urban land classification with Landsat thematic mapper imagery. Remote Sens 6:964-983

Lillesand TM, Kiefer RW (1999) Remote sensing and image interpretation. Wiley, New York

Mertens K, Jacobs L, Maes J, Kabaseke C, Maertens M, Poesen J, Kervyn M, Vranken $L$ (2017) The direct impact of landslides on household income in tropical regions: a case study from the Rwenzori Mountains in Uganda. Sci Total Environ 550:1032-1043

Netra RR, Giardino JR, Vitek J (2014) Characteristics of landslides in western Colorado, USA. Landslides 11:589-603. https://doi.org/10.1007/s10346-013-0412-6

Petley DN, Dunning SA, Rosser K, Rosser NJ (2005) The analysis of global landslide risk through the creation of a database of worldwide landslide fatalities. Landslide Risk Manag 52:367-373

Prothom Alo (2017) Rangamati landslide death toll 118. https://en.prothomalo. com/bangladesh/news/151605/Rangamati-Landslide-death-toll-118. Accessed 22 Jan 2019

Rabby YW, Li Y (2019) An integrated approach to map landslides in Chittagong hilly areas, Bangladesh, using Google earth and field mapping. Landslides 16 : 633-645. https://doi.org/10.1007/s10346-018-1107-9

Rabby YW, Li Y (2020) Landslide inventory (2001-2017) of Chittagong hilly areas, Bangladesh. Data 5(1):4

Rahman MS, Ahmed B, Liping D (2017) Landslide initiation and runout susceptibility modeling in the context of hill cutting and rapid urbanization: a combined approach of weights of evidence and spatial multi-criteria. J Mt Sci 14(10):1919-1937

Rangamati Hill district Council (2011) Overview of Rangamati. http://rhdcbd.org/ old/about_rangamati.php

Samodra G, Chen G, Sartohadi J, Kasama K (2015) Generating landslide inventory by participatory mapping: an example in Purwosari area, Yogyakarta, Java. Geomorphology 306:306-313. https://doi.org/10.1016/j.geomorph.2015.07.035

Sifa SF, Mahmud T, Tarin MA, Haque DME (2019) Event-based landslide susceptibility mapping using weights of evidence (WoEO) and modified frequency ratio (MFRO) model: a case study of Rangamati district in Bangladesh. Geol Ecol Landscapes. https://doi.org/10.1080/24749508.2019. 1619222

Su F, Cui P, Zhang J, Xiang L (2010) Susceptibility assessment of landslides caused by the wenchuan earthquake using a logistic regression model. J Mt Sci 7(3):234-245

Sultana N (2020) Analysis of landslide-induced fatalities and injuries in Bangladesh: 2000-2018. Cogent Soc Sci 6:1737402. https://doi.org/10.1080/ 23311886.2020.1737402

Traore A, Mawenda J, Komba AW (2018) Land-cover change analysis and simulation in Conakry (Guinea), using hybrid cellular-automata and Markov model. Urban Sci 2(2):39. https://doi.org/10.3390/urbansci2020039

UNDP (2017) The CHT has been severely hit by four consecutive disasters in the span of two weeks in June. http://www.bd.undp.org/content/bangladesh/ en/home/presscenter/articles/2017/06/28/news-update-on-recent-disastersin-cht\%2D\%2Djune-2017.html. Accessed 22 Jan 2019

UNPO (2017) Chittagong Hill Tracts: Torrential Rainstorms and Wide-Scale Landslides Leave Thousands Homeless. Available at: https://unpo.org/article/2 0199?id=20199. Accessed 22 Jan 2019

UNRC (2017) Bangladesh: HCTT Response Plan (June-December 2017) Bangladesh | Relief Web," relief web. https://reliefweb.int/report/bangladesh/ bangladesh-hctt-response-plan-june-december-2017. Accessed 01 Jan 2019

Vakhshoori V, Zare M (2016) Landslide susceptibility mapping by comparing the weight of evidence, fuzzy logic, and frequency ratio methods. Geomatics Nat Hazards Risk 7(5):1731-1752. https://doi.org/10.1080/19475705.2016.1144655

Varnes DJ (1978) Slope movement types and processes. In special report 176, landslides: analysis and control (Eds: Schister RL and Krizek RJ) transportation and road research board. National Academy of Sciences, Washington DC, pp 11-33
Wang Q, Li W (2017) A GIS-based comparative evaluation of analytical hierarchy process and frequency ratio models for landslide susceptibility mapping. Phys Geogr 38(4):318-337. https://doi.org/10.1080/02723646.2017.129452

WHO (2017) Landslides Chittagong, Bangladesh. Situation Report-2. WHO, Bangladesh

Yilmaz I (2009) Landslide susceptibility mapping using frequency ratio, logistic regression, artificial neural networks, and their comparison a case study for Kat landslides. Comput Geosci 35:1125-1138

Yuan F, Sawaya KE, Loeffelholz BC, Bauer ME (2005) Land cover classification and change analysis of the twin cities (Minnesota) metropolitan area by multitemporal Landsat remote sensing. Remote Sens Environ 98(2-3):317-328

Zhang H, Huang X (2018) Trend and spatiotemporal distribution of fatal landslides triggered by non-seismic effects in China. Landslides 15:1663-1674

Zhang S, Li R, Wang F, lio A (2019) Characteristics of landslides triggered by the 2018 Hokkaido Eastern Iburi earthquake, Northern Japan. Landslides, 16(9), 1691-1708.

Zillman J (1999) The physical impact of the disaster. In natural disaster management, ed. J. Ingleton, 320. Leicester: Tudor rose holding Itd.

\section{Publisher's Note}

Springer Nature remains neutral with regard to jurisdictional claims in published maps and institutional affiliations.

\section{Submit your manuscript to a SpringerOpen ${ }^{\circ}$ journal and benefit from:}

- Convenient online submission

- Rigorous peer review

- Open access: articles freely available online

- High visibility within the field

- Retaining the copyright to your article

Submit your next manuscript at $\boldsymbol{\nabla}$ springeropen.com 